\title{
Samples taken off Jamestown, Saint Helena Island (South Atlantic Ocean)
}

\author{
GEORGES KOUYOUMONTZAKIS \\ Laboratoire de Stratigraphie et de Paléoécologie, Faculté des Sciences, Centre Saint \\ Charles, Place Victor Hugo, 13331 Marseille Cedex 3, France
}

\begin{abstract}
Three dredgings samples taken off the coast of Saint Helena, reveal two micropalaeontological associations. One is an infralittoral association, characterized by Miliolina (essentially Quinqueloculina), and by Rotaliina with various species of Amphistegina. The other is a circalittoral association, in which the following changes in family distribution may be observed: a decrease in Miliolina and others littoral species, and an increase in Discorbidae, Eponididae, Cibicididae, and Anomalinidae which indicate an increase in sea depth. The presence of relict Amphisteginidae might point to a Holocene stillstand of the transgressive sea.
\end{abstract}

\section{INTRODUCTION}

Saint Helena is situated in the South Atlantic $800 \mathrm{~km}$ east of the mid-ocean ridge and $2,600 \mathrm{~km}$ from the West African coast (Fig. 1). It consists of Miocene to recent basalt volcanics (Abdel-Monem \& Gast, 1987; Baker, 1969 , 1973), forming an island with an area of 120 square kilometres, rising to a height of 2,850 feet above sea level.

Our knowledge of hydrological conditions in the tropical south central Atlantic Ocean is very limited; this study is based on the works of Gallardo (1966), Neumann (1965), and Piton et al. (1977). Surface temperatures of the sea range between $20^{\circ} \mathrm{C}$ and $22^{\circ} \mathrm{C}$ in the vicinity of St. Helena, with salinity between $35 \%$ and $36 \%$.

The three samples studied were collected by the oceanographic vessel "A. Nizery" of the O.R.S.T.O.M. in Pointe Noire, Congo Peoples Republic, by means of a Rallier du Bathy dredge in Jamestown Harbour (15 55'S-5 43'W) (Fig. 1). Dredge sample DSH1 contained two separate sediments, referred to as DSH1a and DSH1b.

The sediments are poorly sorted, and can be classified as muddy sand (DSH1 and DSH3) and sand (DSH2). The carbonate, with a higher percentage in the sand, consists of reworked calcareous algae and madrepores. Molluscan shells are common and the two samples from the shallowest water (DSH2 and DSH3) have abundant amphisteginids (Fig. 2). X-ray diffraction shows the clays to consist of kaolinite, or more rarely smectite interlayering with illite. Table 1 gives details for the samples.

\section{MICROPALAEONTOLOGY}

\section{Ostracoda}

In the region studied the fauna is very limited. Only five species of ostracods have been found, three of which remain in open nomenclature: Ruggeria lekkii Omatsola 1972, R. martinsoni Omatsola 1972, Ruggeria sp., Bairdia sp., Loxoconcha sp.. These species are not unknown in this region; Ruggeria abounds in the Gulf of Guinea, in shallow, coastal waters with a normal salinity (Jouval, 1978; Keen 1972, 1975; Babinot \& Kouyoumontzakis, 1985).

\section{Planktonic Foraminifera}

Planktonic and benthic foraminifera are considered separately. Given the sampling method, the samples may be considered as average representations of the sediment. Since the "birth" of the Saint Helena volcano dates from the end of the Miocene, a mixture of middle Neogene populations and recent ones is quite possible.

Boltovskoy (1968) recorded planktonic species typically found in tropical waters to be represented in these regions by the following percentages: Globigerinoides ruber $36.5 \%, G$. sacculifer $1.5 \%$, G. trilobus $45 \%$, Globoquadrina dutertrei $6.5 \%$, Globorotalia menardii $6.5 \%$ and accessory species $4 \%$, the number of which varies according to the season. These percentages were calculated from samples taken by trawling with a plankton net in the open ocean, whereas the data used in this study was gathered from coastal dredging. The planktonic foraminifera encountered here cannot therefore be easily compared with Boltovskoy's study.

The most important species are Globigerinoides trilobus which represents between $23 \%$ and $45 \%$ of the planktonic species and Globigerinoides ruber, which accounts for between $10 \%$ and $36 \%$ of the population. 


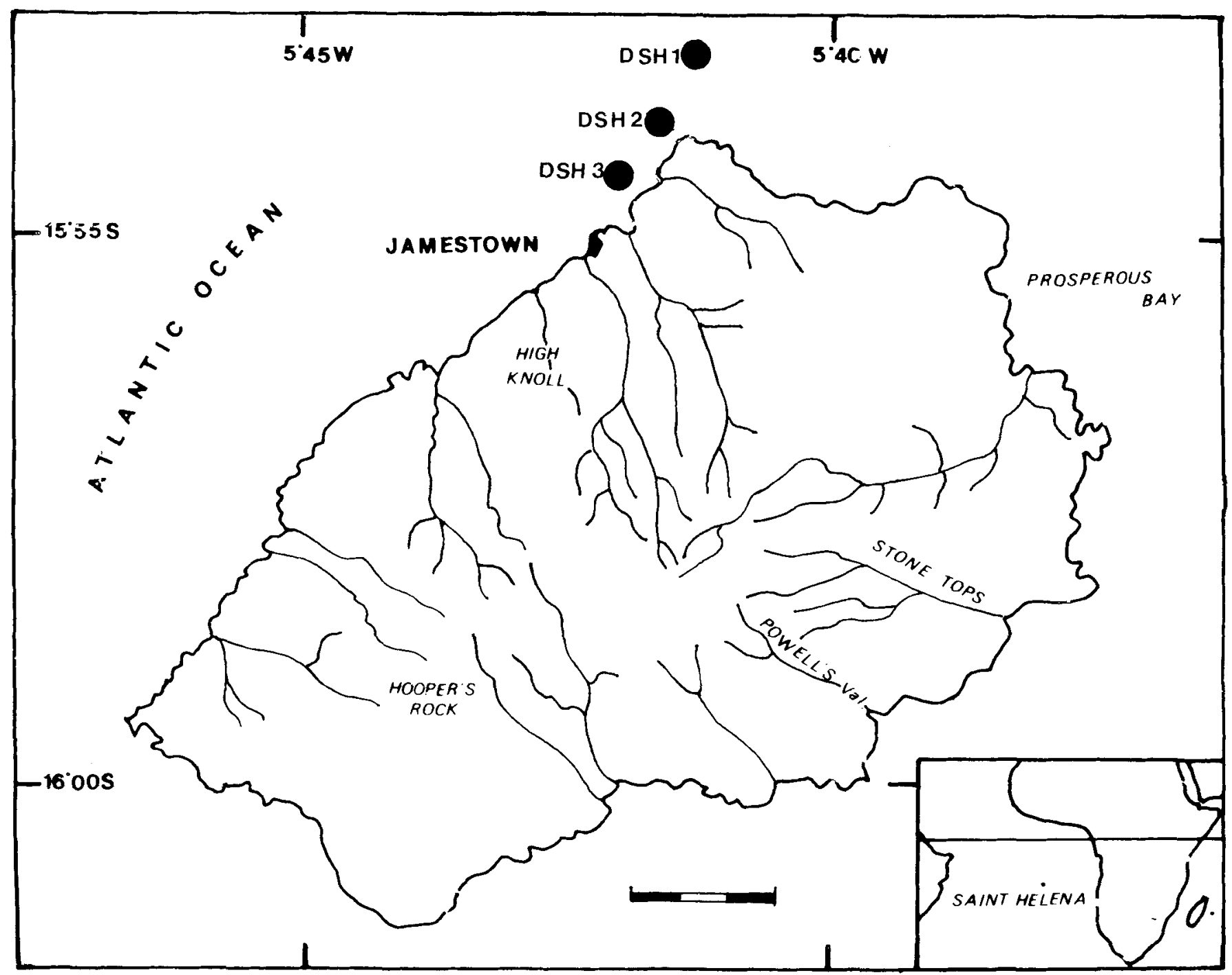

Fig. 1. Saint Helena island, showing dredging samples position.

Globorotalia crassaformis gp. form between $14 \%$ and $35 \%$ of the planktonic fauna, being more abundant in the samples from deeper water. The quantity of the planktonic species as a percentage of the total foraminifera microfauna increases with depth: $7.5 \%$ of the microfauna at $50 \mathrm{~m}$, compared with $32 \%$ at $96 \mathrm{~m}$ (Table 2).

\section{Benthic Foraminifera}

There is very little difference between the microfauna encountered in this study, and that found on the African coasts (Kouyoumontzakis, 1982). Sixty species are found of which seven are in open nomenclature. Textulariina are almost totally absent from the studied sediments. Two thirds of the species found are often represented by a single specimen, and have therefore only a limited value (Table 3 ).

Eleven species are commonly present: Quinqueloculina kerimbatica, $Q$. pulchella, $Q$. pseudoreticulata, $Q$. venusta, Lenticulina suborbicularis, Eponides repan- dus, Amphistegina bilobata, A. gibbosa, A. lessonii, $A$. radiata and Ceratobulimina pacifica. Seven species found in these sediments are not encountered on the continental shelf of the gulf of Guinea: Quinqueloculina aff. crenulata, $Q$. pseudoreticulata, $Q$. venusta, Massilina robustior, Lenticulina atlantica, Ceratobulimina pacifica, Lamarckina atlantica.

The absence of Textulariina could be attributed to hydrological factors, or to the fact that agglutinated foraminifera are unable to find particles that are fine enough for them to form their test. The quantity of Miliolina is more or less constant at around $13 \%$, mainly represented by five species: Quinqueloculina pulchella, $Q$. venusta, $Q$. kerimbatica, $Q$. pseudoreticulata and $Q$. aff. crenulata.

The number of Rotaliina varies between $45 \%$ (DSH1) and 79\% (DSH3) depending on the presence or absence of Amphisteginidae. This family, the percentage of which are very high in the two most 
littoral sediments, DSH3 $(50 \mathrm{~m}) 77 \%$ and DSH2 $(75 \mathrm{~m})$ $72 \%$, is renowned for its reef way of life, and its presence in Gulf of Guinea is well known (Kouyoumontzakis, 1982; Lagaaij, 1973). The state of wear of these Amphisteginidae makes it possible to compare them with those found on the Congolese continental shelf, and could correspond to a stillstand of the sea during the Holocene transgression; this

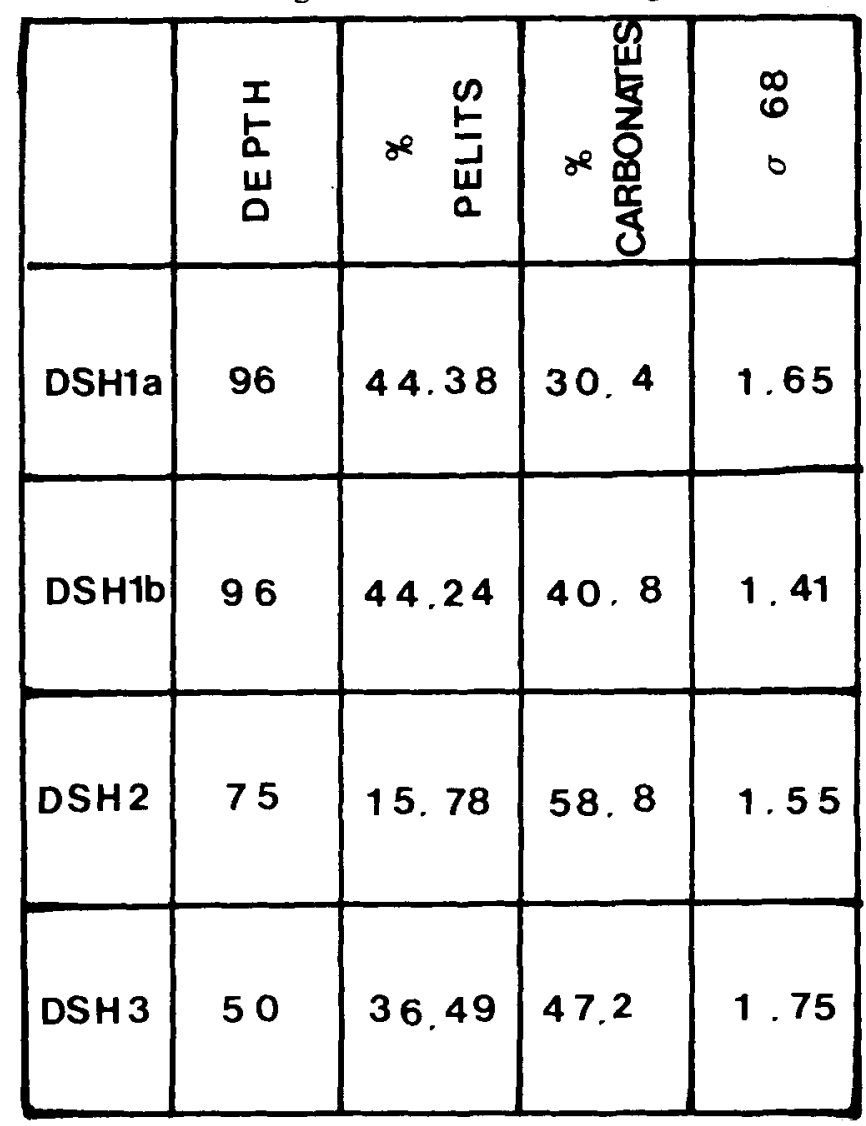

Table 1. Sedimentological characters of the samples. thanatocoenosis dates from 12,000 years B.P. off the coast of the Congo (Delibrias et al., 1973). Radiocarbon dating was not carried out since too few Amphisteginidae tests were picked out.

In the deepest sediments (DSH $1 \mathrm{~b}$ and DSH 1a), littoral species are replaced by Rotaliina whose habitat is circalittoral. Amphisteginidae account for only $25 \%$ of the benthic microfauna in these areas; the species which take their place are Lenticulina suborbicularis, Eponides repandus, Eponides repandus var. concomeratus, Ceratobulimina pacifica.

\section{CONCLUSIONS}

The study of just three dredging samples cannot serve as a basis for generalizations concerning associations of Foraminifera around Saint Helena island, but the study does demonstrate that the microfauna found here is quite similar to that encountered on the coasts of the Gulf of Guinea, and this is true for both Ostracoda and Foraminifera.

Schematically, two associations of Foraminifera can be defined (Fig. 2): The first association from depths of up to $75 \mathrm{~m}$ includes calcareous algae, and could correspond to an infralittoral fauna characterized by Spiroloculina concava, Quinqueloculina kerimbatica, $Q$. aff. crenulata, $Q$. pseudoreticulata, $Q$. venusta, Amphistegina bilobata, A. gibbosa, A. lessonii, A. radiata. The sediments are characterized by quite high levels of $\mathrm{CaCO} 3 ; 58.8 \%$ and $47.2 \%$. These calcium carbonate level are due to the presence of numerous calcareous algal arbusculs and large foraminifera. The Amphisteginidae could be the type of foraminifera that produces the most calcium carbonate. Experiments conducted in the Pacific ocean, show that Amphistegina madagascariensis produces $500 \mathrm{~g}$ of $\mathrm{Ca} \mathrm{CO} 3$ by square meter every year (Muller, 1974).

\begin{tabular}{|l|r|r|r|r|r|}
\hline SPECIES & DSH3 & DSH2 & DSH1a & DSH1 b & BOLTOVSKOY \\
\hline Globorotalia crassaformis \& aff. & 17,1 & 14,7 & 32 & 35,7 & \\
\hline G. menardi & 15 & 11 & 8,5 & 5,6 & 6,5 \\
\hline G. scitula & & & 1,5 & 0,5 & \\
\hline G. tumida & 2,2 & 2,5 & 6,4 & 1,7 & \\
\hline G. truncatulinoides & 1,4 & 1,6 & 2,4 & 0,9 & \\
\hline Globoquadrina dutertrei & 2,2 & & 0,6 & 4,7 & 6,5 \\
\hline Globigerinoides conglobatus & & 4,5 & & 0,9 & \\
\hline G. ruber & 20 & 20 & 10,3 & 12 & 36,5 \\
\hline G. sacculifer & 0,7 & 1 & 6 & 3,3 & 1,5 \\
\hline G. trilobus & 40 & 43 & 23 & 32,5 & 45 \\
\hline Orbulina universa & 0,7 & 0,7 & 0,3 & 0,5 & 1,6 \\
\hline Pulleniatina obliquiloculata & 0,7 & 1 & 1,8 & 1,6 & 96 \\
\hline TOTAL & 100 & 100 & 92,8 & 99,9 & \\
\hline
\end{tabular}

Table 2. Numerical repartition of planktonic species. 
The second association for which only one sample was found, can be termed circalittoral, and is characterized by an increase in the quantity of benthic Rotaliina: Lenticulina suborbicularis, Cancris auriculatus, Eponides repandus, Eponides repandus var. concomeratus, Cibicididae, Anomalinidae and Ceratobulimina pacifica. It is also characterized by a decrease in the number of Amphisteginidae. A striking fact is the absence of the Textulariina in these littoral environments, which are poor in fine particles.

The presence of relict Amphisteginidae would seem to indicate that the sea level has undergone fluctuations, and that the overall eustatic schema of the Gulf of Guinea may be applied to this island.

\section{Manuscript received September 1987}

Revised manuscript accepted October 1988

\section{REFERENCES}

Abdel-Monem, A., Gast P. W. 1967. Age of volcanism on St. Helena. Earth and Planetary Sci. Letters 2 415-418.

Baker, I., 1969. Petrology of the volcanic rocks of Saint Helena Island, South Atlantic. Geol. soc. Amer. Bull., 80, 1283-1310.

Baker, I., 1973. Islands of the South Atlantic In Nairn. A.E.M., Stehli, F. G. (Eds.) The oceans basins and margins, Plenum Press, New York, London, 493-553.

Boltovskoy, E., 1969. Living planktonic foraminifera of the Eastern part of the tropical Atlantic. Rev. Micropal., 11,2, 85-89.

Delibrias, G., Giresse. P. \& Kouyoumontzakis. G., 1973. Géochronologie des divers stades dans la transgression holocène au large du Congo. C. R. Acad. Sci. Paris, 276 (26 février 1973) série D, 1389-1391.

Gallardo, Y., 1966. Contribution à l'hydrologie du Bassin de l'Angola. Doc. Sci, Centre O.R.S.T.O.M. Pointe-Noire, 345 SR.

Jouval, J., 1978. Microfossiles de la Côte d'Ivoire, Foraminifères et Ostracodes. Le Néogéne et la limite PaléocéneNéogéne. Thése doct. Béme cycle Univ. Aix-Marseille I.

Keen, M. C., 1972. Recent ostracod assemblages from the coast and shelf of Sierra Leone. Actes du IV. Coll. Africain de Micropal., 195-208.

Keen, M. C., 1975. Some Ruggieria-like ostracods from the Tertiary and Recent of West Africa. Proc. V. African Coll. on Micropal., 451-469, 2pl.

Kouyoumontzakis, G., 1982. Les associations de Foraminifères du plateau continental congolais: Foraminifères benthiques. Cahiers de Micropaléontologie (2), 155-162.

Kouyoumontzakis, G., 1984. Les Amphisteginidae (Foraminifera) du plateau continental congolais, dans le cadre de la marge ouest africaine. Revue de Micropaléontologie 27, 3 , 196-208.

Lagaiij, R., 1973. Shallow water Bryozoa from Deep-sea Sands of the Principe Channel, Gulf of Guinea, in Larwood G. P. Edit., Living and Fossil Bryozoa London, Academic Press, 139-152.
Muller, P. H., 1974. Sediment production and population biology of the benthic foraminifera Amphistegina madagascariensis. Limology \& Oceanography 19, 5, 802-809.

Neumann, G., 1964. Oceanography of the Tropical Atlantic. Acad. Brasiliera Cien., 37, 62-72.

Piton, G., Perrin, R. \& Gausi. J. P. 1977. Nouvelles considérations sur les saisons marines et la circulation dans le Golfe de Guinée. Doc. Sci., Centre O.R.S.T.O.M. Pointe-Noire, 49 nlle. série.

\begin{tabular}{|c|c|c|c|c|}
\hline SPECIES & DSH3 & DSH2 & DSH1a & DSH1b \\
\hline Spiroloculina excavata & & & & 0,04 \\
\hline S. concava & 1 & 0,75 & 0,3 & 0,7 \\
\hline S. tenuimargo & 0,05 & & & \\
\hline S. $s \rho$. & & & 0,07 & \\
\hline Quinqueloculina bicarinata & 0,4 & & & 0.08 \\
\hline Q. cliarensis & & & & 0.04 \\
\hline O. aff. crenulata & 0,3 & & & \\
\hline Q. disparilis & & & 0,07 & \\
\hline Q. kerimbatica & 2 & 1,1 & 0,4 & 0,32 \\
\hline Q.lamarckiana & 0,1 & 0.5 & & 0.12 \\
\hline Q.pulchella & 6,16 & 5,4 & 11,1 & 8,5 \\
\hline Q. pseudoreticulata & 0,4 & & & \\
\hline Q. schlumbergerii & 4 & & & \\
\hline Q. seminulum & & 0,7 & & 0,23 \\
\hline Q. venusta & 1,4 & 0,2 & 1,6 & 1,5 \\
\hline O.ssp. & 0,6 & 1,7 & 0,7 & 2,02 \\
\hline Biloculina labiata & & 0.07 & 0,23 & 0.08 \\
\hline Massilina robustior & & & & 0.08 \\
\hline Amphicoryna scalaris & 0,15 & & 0,23 & 1,5 \\
\hline Nodosaris catesbyi & & 0,45 & 0,48 & \\
\hline Lenticulina atlantica & 0.05 & 0,07 & 0,23 & 0,12 \\
\hline L. aff calcar & & 0,03 & & \\
\hline L. cultrata & & & 0,07 & 0,04 \\
\hline L. suborbicularis & 0,1 & 1,2 & 5,7 & 3,2 \\
\hline Marginulina aft costata & & & & 0,4 \\
\hline Frondicularia $s p$ & & & & 0.04 \\
\hline Glandulina laevigata & & 0,03 & & \\
\hline Bolivina aff. striata & & & & 0,02 \\
\hline Brizalina sp. & 0,05 & & & \\
\hline Rosalina candeina & 0,1 & 0,03 & & 0,04 \\
\hline Cancris auriculatus & & & & 1,3 \\
\hline C. oblungus & 0,05 & 0,03 & & \\
\hline C. sagrum & & & 0,23 & 0,18 \\
\hline Siphonina aft. bradyana & & 0.03 & & \\
\hline S. reliculata & & & & 0,08 \\
\hline Rotalia sp. & 0,05 & & & 0,04 \\
\hline Ammonia beccarii & & & & 0,08 \\
\hline Eponides repandus & 1.2 & 3,5 & 6,8 & 3,75 \\
\hline E. repandus var. concomeratus & 0,4 & 0,17 & & 1,6 \\
\hline E. procerus & & & 0.23 & \\
\hline Poroeponides lateralis & 0,1 & & 0,48 & \\
\hline Elphidium complanatum & 0,05 & & & \\
\hline Cribroelphidium sp. & & 0,03 & & \\
\hline Amphistegina spp & 73 & 72 & & \\
\hline Amphistegina bilobata & & & 0,94 & 0,9 \\
\hline A. gibbosa & & & 9,2 & 29 \\
\hline A lessonii & & & 19.2 & 3,9 \\
\hline A. radiata & & & 4,11 & 11,7 \\
\hline Cibicides lobatulus & & & 0,07 & 0,04 \\
\hline C. pseudoungerianus & & & 0,03 & 0,12 \\
\hline C. umbonatus & & 0,17 & & 0.04 \\
\hline Planorbulina mediterranensis & & 0,03 & & 0,04 \\
\hline Planulina sp. & & 0,03 & & \\
\hline Sphaerogypsina globulus & & 0,14 & & \\
\hline Cassidulina laevigata & & & & 0,04 \\
\hline Osangularia sp. & & & & 0.4 \\
\hline Gyroidina $s p$ & & 0,03 & & 0,12 \\
\hline Hanzawaia nitidula & & 0,03 & & 0,04 \\
\hline H. ornata & & & & 0,04 \\
\hline Rabertina bradyi & & & & 0,04 \\
\hline Ceratobulimina pacifica & 0,3 & 1,2 & 10,7 & 12,3 \\
\hline Lamarckina atlantica & & & 0,3 & 0,42 \\
\hline BENTHICS & 92,5 & 89,3 & 74 & 64,3 \\
\hline PLANKTONICS & 7,5 & 10,7 & 26 & 35,7 \\
\hline
\end{tabular}

Table 3. Numerical repartition of benthic species. 


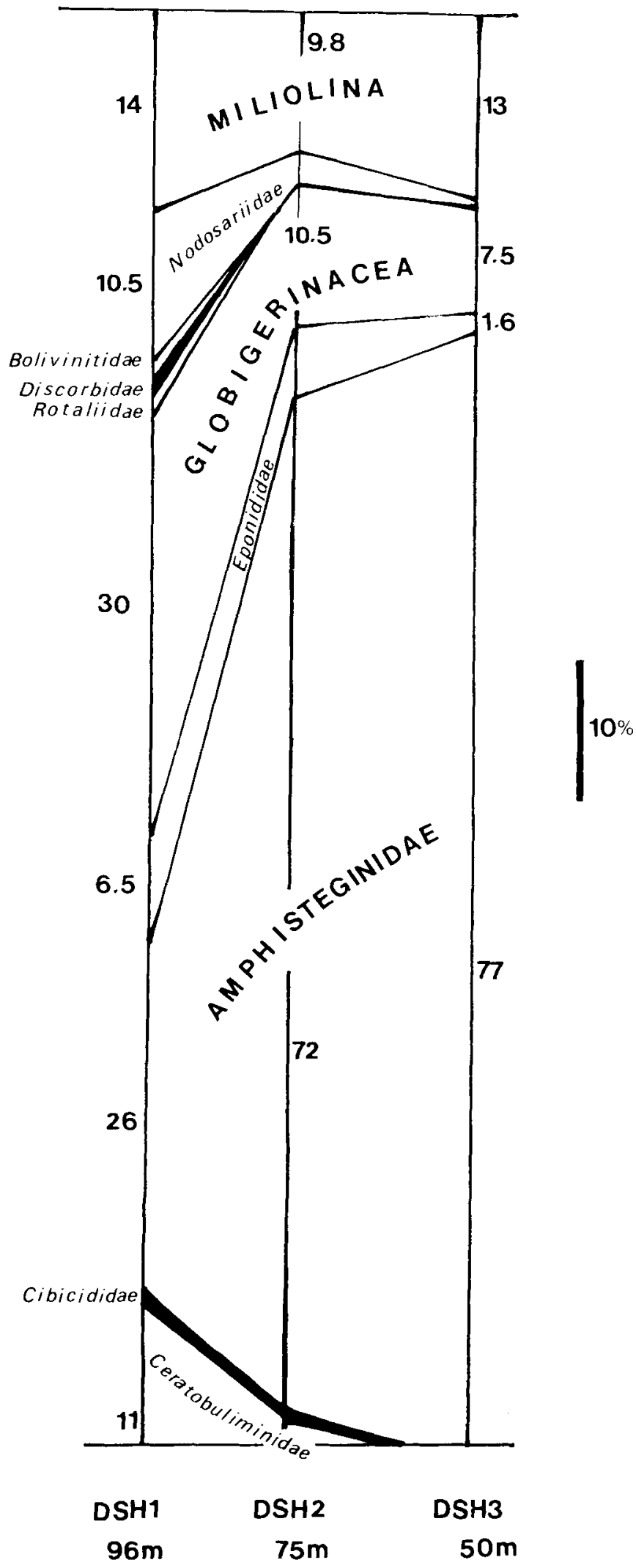

Fig. 2. Composition of foraminiferal fauna in the samples.

\section{APPENDIX \\ TAXONOMIC LIST}

\section{BENTHIC FORAMINIFERA}

Spiroloculina excavata

S. concava

S. tenuimargo

S. Depressa

Quinqueloculina disparilis

$Q$. bicarinata

$Q$. cliarensis

$Q$. aff. crenulata

Q. kerimbatica

$Q$. pulchella

Q. pseudoreticulata

$Q$. schlumbergerii

Q. seminulum

$Q$. venusta

Biloculina labiata

Massilina robustior

Amphicoryna scalaris

Nodosaria catesbyi

Lenticulina atlantica

$L$. aff. calcar

L. cultrata

L. suborbicularis

Marginulina aff. costata

Frondicularia $s p$.

Glandulina laevigata

Bolivina aff. striata

Brizalina $s p$.

Rosalina candeina

Cancris auriculatus

C. oblungus

C. sagrum

Siphonina aff. bradyana

$S$. reticulata

Rotalia $s p$.

Ammonia beccarii

Eponides repandus

E. repandus (F.\&M.)

var. concomeratus

Poroeponides lateralis

Elphidium complanatum

Cribroelphidium $s p$.

Amphistegina bilobata

A. gibbosa

A. lessonii

A. radiata

Cibicides lobatulus

C. umbonatus

Planorbulina

mediterranensis

Planulina $s p$.

Sphaerogypsina globulus

Cassidulina laevigata

Osangularia sp. Hanzawaia nitidula

H. ornata

Robertina bradyi

Ceratobulimina bradyi

Lamarckina atlantica
d'Orbigny, 1846

Petri, 1954

Cushman, 1917

d'Orbigny, 1826

d'Orbigny, 1825

d'Orbigny, 1826

Heron-Allen \& Earland, 1930

Cushman, 1932

(Heron-Allen \& Earland, 1930)

d'Orbigny, 1826

Parr, 1959

(Heron-Allen \& Earland, 1930)

(Linné, 1758)

Karrer, 1868

(Schlumberger, 1891)

Cushman \& Valentine, 1939

Barker, 1960

d'Orbigny, 1839

Barker, 1960

(Linné, 1767)

(de Montfort, 1808)

Parr, 1950

(Batsch, 1791)

(d'Orbigny, 1826)

Cushman, 1922

d'Orbigny, 1839

de Montfort, 1808

(Williamson, 1858)

Cushman \& Todd, 1942

Cushman, 1927

(Czjezk, 1848)

(Linné, 1758)

(Fichtel \& Moll, 1803)

(Williamson, 1858)

(Terquem, 1878)

(d'Orbigny, 1839)

d'Orbigny in Fornasini, 1903

d'Orbigny, 1839

d'Orbigny, 1826

Terquem, 1880

(Walker \& Jacob, 1798)

Phleger \& Parker, 1951

d'Orbigny, 1826

(Reuss, 1847)

d'Orbigny, 1826

Bandy, 1953

Le Calvez, de Klasz

\& Brun, 1971

Cushman \& Parker, 1936

Cushman \& Harris, 1927

Cushman, 1931 


\section{PLANKTONIC FORAMINIFERA}

Globorotalia crassaformis (Galloway \& Wissler, 1927)

G. menardii

G. scitula

(d’Orbigny, 1826)

G. tumida

(Brady, 1882)

(Brady, 1884)

G. truncatulinoides (d'Orbigny, 1839)

Pulleniatina obliquiloculata (Parker \& Jones, 1862)

Globoquadrina dutertrei (d'Orbigny, 1839)

Globigerinoides

conglobatus

(Brady, 1879)

G. ruber

G. sacculifer

G. trilobus

(d'Orbigny, 1839)

(Reuss, 1850)

Orbulina universa d'Orbigny, 1839

Fig. 1. Spiroloculina excavata $(\times 30)$.

Fig. 2. Spiroloculina concava $(\times 30)$.

Fig. 3. Quinqueloculina cliarensis $(\times 20)$.

Fig. 4. Quinqueloculina pulchella $(\times 30)$.

Fig. 5. Quinqueloculina kerimbatica $(\times 30)$.

Fig. 6. Quinqueloculina aff. crenulata $(\times 60)$.

Fig. 7. Quinqueloculina venusta $(\times 60)$.

Fig. 8. Amphicoryna scalaris $(\times 60)$.

Fig. 9. Lenticulina suborbicularis $(\times 30)$.

Fig. 10. Bolivina sp. $(\times 60)$.

Fig. 11. Lenticulina atlantica $(\times 30)$.

Fig. 12a. Eponides repandus, spiral side $(\times 30)$.

Fig. 12b. Eponides repandus, ombilical side $(\times 30)$.

Fig. 13. Amphistegina gibbosa, reworked test $(\times 30)$.

Fig. 14. Amphistegina gibbosa, lateral view $(\times 30)$.

Fig. 15. Amphistegina lessonii $(\times 20)$.

Fig. 16. Cancris auriculatus $(\times 30)$.

Fig. 17a. Ceratobulimina pacifica, spiral side $(\times 30)$.

Fig. 17b. Ceratobulimina pacifica, ombilical side $(\times 30)$. 

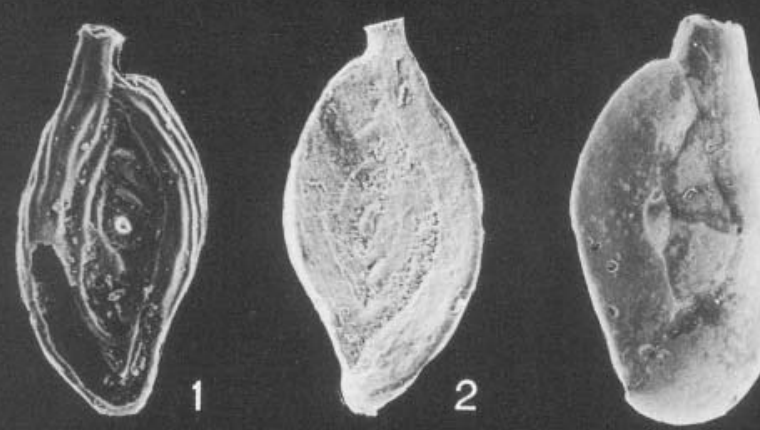

3
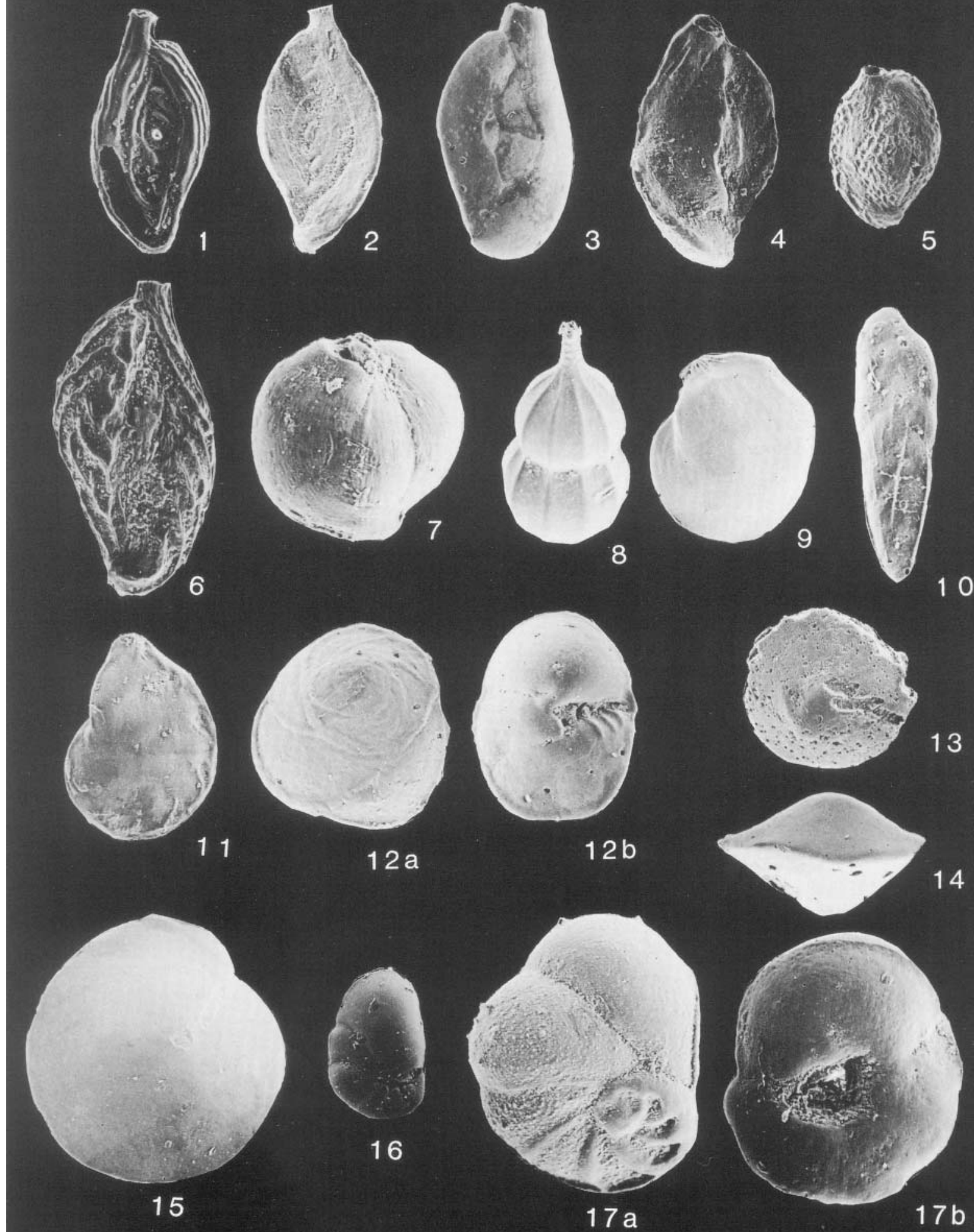